\title{
In silico characterization of hypothetical proteins obtained from Mycobacterium tuberculosis H37Rv
}

\author{
${\text { Utkarsh } \text { Raj }^{1} \cdot \text { Aman Kumar Sharma }}^{2}$ Imlimaong Aier ${ }^{1} \cdot$ Pritish Kumar Varadwaj $^{1}$
}

Received: 28 September 2016/Revised: 13 December 2016/Accepted: 24 January 2017/Published online: 4 February 2017

(C) Springer-Verlag Wien 2017

\begin{abstract}
Tuberculosis is one of the oldest diseases with a death rate of 1.5 million per year. Tuberculosis spreads from one person to another through Mycobacterium tuberculosis. This bacteria belongs to the family $M y$ cobacteriaceae, genus Mycobacterium, member of the tuberculosis complex. Mycobacterium tuberculosis is an acid-fast, aerobic, rod-shaped bacteria, ranging from 2 to $4 \hat{\mathrm{A}} \mu \mathrm{m}$ in length and 0.2 to $0.5 \hat{\mathrm{A}} \mu \mathrm{m}$ in width. Tuberculosis spreads through infected people via sneezing, coughing, etc., with humans acting as the host for the bacteria. The genome of Mycobacterium tuberculosis $H 37 R v$ encodes 3906 proteins, of which 1055 are hypothetical proteins (HPs), wherein the functions of the proteins are unknown. The sequences of 1055 HPs of Mycobacterium tuberculosis were analyzed and the functions of 578 HPs were subsequently predicted with a high level of confidence. Several enzymes, transporters and binding proteins of 1055 HPs in M. tuberculosis were analyzed and potential targets were discovered which contribute to the overall survival of the bacteria. The analysis will be of relevance in understanding the mechanism of the bacteria and will prove to be beneficial in the discovery of new drugs.
\end{abstract}

Electronic supplementary material The online version of this article (doi:10.1007/s13721-017-0147-8) contains supplementary material, which is available to authorized users.

Pritish Kumar Varadwaj

pritish@iiita.ac.in

1 Department of Applied Sciences, Indian Institute of Information Technology-Allahabad, \#CC2-4203, Jhalwa Campus, Deoghat, Allahabad, Uttar Pradesh 211012, India

2 Department of Applied Chemistry, Sardar Vallabhbhai National Institute of Technology, Surat, Gujarat, India
Keywords Mycobacterium - Hypothetical proteins . Functional annotation $\cdot$ ROC analysis

\section{Introduction}

Tuberculosis is one of the oldest and most dangerous diseases in the world. Death rate due to tuberculosis is more than 1.5 million per year despite various vaccines being used worldwide. The causative organism responsible for this disease was identified as Mycobacterium tuberculosis, a bacteria which belongs to the genus Mycobacterium.

Mycobacterium tuberculosis is a bacteria related to the family Mycobacteriaceae and is the main organism responsible for causing tuberculosis (Munksgaard 2004), which is spread from one person to another through the air. This bacteria is normally found in air in the form of aerosol droplets of size $1-5 \mu \mathrm{m}$ in diameter. This aerosol droplet nuclei is dispersed into the air when a person suffering from tuberculosis sneezes or coughs. The bacteria has a waxy coating on its cell surface, which is due to the presence of mycolic acid. Mycobacterium tuberculosis is gram positive (Fu and Fu-Liu 2002) and is immobile. It is an acid-fast aerobic rod of length $2-4 \mu \mathrm{m}$ and width $0.2-0.5 \mu \mathrm{m}$. It divides over a time period of $15-20 \mathrm{~h}$, spreading very slowly in the human lung (Munksgaard 2004).

The advancement of the field of genomics especially next generation sequencing analytical techniques have been brought about by the collection of large number of sequences obtained from various different bacterial strains (Mazandu and Mulder 2012; Kamal et al. 2016a; Gupta et al. 2016). Though nearly $40-50 \%$ of genes within a genome are classified in the category of 'unknown', 'hypothetical' or 'conserved hypothetical' or 'orphan' genes, 
constraining our comprehension of virulence and pathogenicity of the various species of bacteria (Kumar and Shanmughavel 2011; Kamal and Nimmy 2016), the genome sequence of Mycobacterium tuberculosis is available in the NCBI database which contains 4019 genes encoding 3906 proteins. Out of 3906 proteins, the function and characterization of 1055 proteins are unknown and are thus considered as hypothetical proteins. Various bioinformatics tools were employed for predicting and understanding the function of these hypothetical proteins. The current protocol used in this study can likewise be connected to annotate the uncharacterized proteins from other prokaryotic and eukaryotic life forms (Chowdhury et al. 2016). This analysis will prove to be beneficial in understanding the mechanism of the bacteria; beneficial to the discovery of new drugs and could significantly impact TB control and vaccine development strategies.

\section{Related work}

The functional characteristic of various Mycobacterium tuberculosis $\mathrm{H} 37 \mathrm{Rv}$ proteins annotated as hypothetical proteins are yet to be performed. The current study includes various in silico approaches to identify and annotate the biological role and function of unknown $M y$ cobacterium tuberculosis $\mathrm{H} 37 \mathrm{Rv}$ hypothetical proteins. The presence of HPs in genomes is crucial for the overall comparative as well as functional genomics analyses. Specifically for pathogenic organisms, these HPs hinder the search for novel drug targets, and diminish the scope of our understanding to study various virulence and pathogenic properties (Gupta et al. 2016). Earlier studies reported the functions of only 250 HPs of Mycobacterium tuberculosis using various Bioinformatics web tools, BLAST, INTERPROSCAN, PFAM and COGs (Kumar and Shanmughavel 2011). But in-depth study and analysis is yet to be carried out for the function prediction and characterization of 1055 HPs obtained from Mycobacterium tuberculosis H37Rv.

\section{Materials and methods}

\subsection{Sequence retrieval}

From the NCBI database (http://www.ncbi.nlm.nih.gov/ genome), the genome of Mycobacterium tuberculosis was retrieved in the FASTA format. There are 3906 proteins present, out of which 1055 proteins are characterized as hypothetical proteins because the function and characterization of these proteins are unknown. The sequences of these 1055 HPs have been collected from the above-mentioned NCBI database in the form of FASTA sequences which were further validated from UNIPROT database and the redundant proteins were excluded. Only unique HPs were taken further for the functional annotation and characterization through various analysis such as physiochemical properties calculation, subcellular localization and sequence comparisons, protein function and domain analysis, virulence factor analysis, etc. The overall methodology has been mentioned in the form of schematic representation as shown in Fig. 1. This was further explained by making a flowchart of various steps involved in the computational and functional annotation of HPs.

\subsection{Physicochemical characterization}

Data related to these hypothetical proteins were found to be insufficient, and thus the Expasy's ProtParam server (Gasteiger et al. 2003; Raj et al. 2015) was used to determine the physiochemical properties of a protein that can be obtained from its sequence like molecular weight, extinction coefficient, isoelectric point, instability index, aliphatic index and grand average of hydropathicity (GRAVY). The information obtained from the server was found to be essential for analyzing the function of the HPs. The predicted physicochemical properties of 1055 HPs are listed in S1 Table.

\subsection{Subcellular localization}

After predicting the physicochemical property of the hypothetical proteins, the location of proteins will be analyzed. Subcellular localization is more helpful for prediction of the drug target and vaccine target. HPs can be present anywhere in the cell, for instance the cytoplasm, periplasm, extracellular, inner membrane, and outer membrane. Proteins present in the cytoplasm play an essential role in the prediction of drug target, while outer or inner localized proteins work as vaccine targets. PSORTb (Nancy et al. 2010) and CELLO (Yu et al. 2006) were used for subcellular localization of the protein. PSORTb is a database which describes the location of proteins in the cell and provides a more accurate collection of experimental data as compared to CELLO. PSORTb requires a sequence of the protein to be submitted in the FASTA format, after that the organism type as well as its gram stain was selected. As we have taken Mycobacterium tuberculosis H37Rv strain, we selected Gram stain as gram + ve in this case. SignalP 4.1 (Emanuelsson et al. 2007) was used for predicting signal peptide and TMHMM (Krogh et al. 2001) was used for the prediction of the transmembrane helices in protein. The subcellular localization predictions of 1055 HPs are listed in the S2 Table. The inbuilt parameter of the cut-off values used in the case of SignalP 4.1 is chosen to optimize the performance which can be measured as 


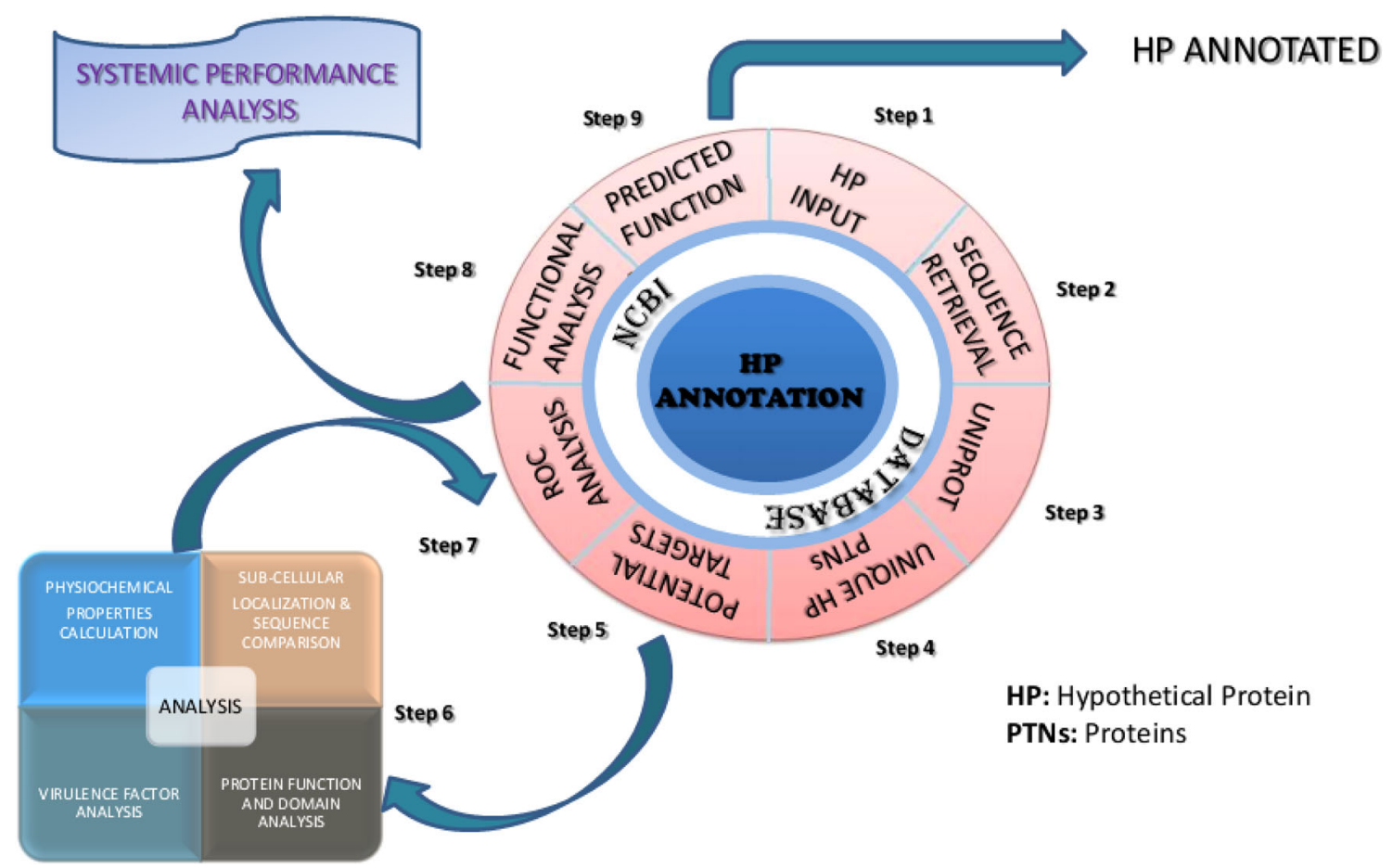

Fig. 1 Schematic representation of the various steps involved in annotation of HPs

Matthews Correlation Coefficient (MCC). This results in a lower sensitivity (true positive rate) than SignalP 4.0 possess. One of the peculiar factors of using TMHMM is that it becomes possible to model helix length, which has just been done reasonably roughly in most different techniques, by fixing upper and lower limits for the length of a membrane helix.

\subsection{Sequence comparisons}

In subcellular localization, the location of the HPs was defined. The sequences of HPs were analyzed by using BLASTP (Altschul et al. 1990; Raj et al. 2015) and HHPred (Söding et al. 2005). BLASTP is an algorithm for the prediction of similar sequences of HPs which provides 100 similar sequences of HPs. Proteins with high identity values are considered as more identical with HPs, while less identity values are considered as remote homologues. We have used the non-redundant database for the similarity search using the default parameters of the BLASTP. The $E$ value should be filled with a number, such as $1,10,0.01$ or $1.0 \mathrm{E}-5$. This setting specifies the statistical significance threshold for reporting matches against database sequences. If the statistical significance ascribed to a match is greater than the EXPECT threshold, the match will not be reported. Lower EXPECT thresholds are more stringent, leading to fewer chance matches being reported. HMMSCAN (Gough et al. 2001) was used to search the
Pfam, SUPERFAMILY, TIGRFAMs and Gene3D databases for protein with similar families and domains. The list of predicted similar sequence and function values of 1055 HPs are given in S3 Table.

\subsection{Function prediction}

Proteins are classified into families and superfamily on the basis of their sequence, structure and function by various protein classification tools like CATH, SCOP, etc. Based on sequence similarity, Pfam database was used to predict the function of proteins. INTERPROSCAN is a tool to describe the function, domain, family, location of protein at a time. To group proteins along these categories, InterPro uses predictive models, $\mathrm{k} / \mathrm{a}$ as signatures, provided by few unique databases (referred to as part databases) that make up the InterPro consortium. SUPERFAMILY (Gough et al. 2001) was used to predict the functional and structural annotation of hypothetical protein. Results of function prediction based on these tools are listed in the S4 Table.

\subsection{Virulence factors analysis}

Virulence factor plays an important role in the prediction of drug target. Virulence factor gives a description about more active proteins which play important roles for the function and survival of pathogens. VICMPred (Saha and Raghava 2006) and VirulentPred (Garg and Gupta 2008) were 
employed for the analysis of virulence factor. The VICMPred server allows the prediction on the basis of three different approaches, i.e., patterns based; patterns based and amino acid composition; patterns based and amino acid composition and dipeptide composition. In this case, we have selected pattern-based approach. The tool VirulentPred gives a more accurate prediction of virulence factors as compared to VICMPred. Results of virulence factor prediction based on these tools are listed in the S5 Table.

\subsection{Protein annotation prediction}

Receiver operating characteristics (ROC) analysis was used for verifying the predicted function of HPs in Mycobacterium tuberculosis. The first 100 protein sequences were selected for statistical analysis (S6 Table), while the first 10 are displayed in Table 1. Prediction of these protein functions was made and the efficacy for these diagnostics was evaluated at five levels. True positives and true negatives predicted were classified as " 0 " and " 1 ". The confidence rating for the predicted functions was given a rank from 1 to 5 (Kamal et al. 2016b). In this curve, the true positive rate (sensitivity) is plotted in function of the false positive rate (100-specificity) for different cut-off points of a parameter. Each point on the ROC curve represents a sensitivity/specificity pair corresponding to a particular decision threshold.

\section{Results and discussion}

The genome of the H37Rv strain containing 4 million base pairs was published in 1998 (Ioerger et al. 2010). The genome sequence of Mycobacterium tuberculosis is available in the NCBI database containing 4019 genes, encoding 3906 proteins. Out of 3906 proteins, the function and characterization of 1055 proteins are unknown and are classified as hypothetical proteins. Tools such as Pfam, INTERPROSCAN, SUPERFAMILY, HMMSCAN, CELLO, PSORTb, SignalP, Expasy, VirulentPred, VICMPred and TMHMM were used for the prediction of function (Raj et al. 2016), family, domain, superfamily subcellular localization, physicochemical properties and virulence factor of HPs of Mycobacterium tuberculosis, out of which 578 HPs were predicted with high level of confidence (S6 Table and S7 Table) while 477 HPs of low level of confidence were also predicted. All of these 578 HPs were categorized into various functional classes containing 158 enzymes, 36 binding proteins, 66 transporters, 32 cellular process/regulatory proteins, 53 virulent proteins, 20 ATP proteins, 31 membrane proteins and the rest as miscellaneous proteins as depicted in Fig. 2.

\subsection{Enzymes}

Details of enzymes are important in understanding the function and activities of microorganisms in order to predict drug targets (Raj et al. 2015). 158 enzymes were characterized, out of which 81 oxidoreductase enzymes were identified. These enzymes are necessary for the transfer of electrons from one part of the bacteria to the other (Nambi et al. 2015). 7 proteins were identified as radical SAM (S-adenosylmethionine) proteins (Cantoni 1952). SAM is an enzyme which plays an important role in the transfer of methyl group within the body. 11 HPs with kinase activity were also identified, whose roles are to transfer phosphate group.

Similarly, 47 transferase enzymes which provide the pathway for the transfer of methyl or glycosyl functional groups were identified. 4 proteins were identified as lactamase, which decrease the function of antibiotics like penicillin. 31 hydrolase enzymes, responsible for hydrolysis of bonds were annotated. 1 lyase enzyme playing a significant role in the breaking of new bonds and creating ring structures was found to be present. 18 cyclase enzymes involved in the formation of cyclic compounds were identified.

4 isomerase and 5 ligase proteins were also identified. Isomerase enzymes are involved in structural rearrangement of molecule (Noda-García et al. 2015), while ligase enzymes are involved in combining two large molecules into a new molecule. 14 reductase enzymes were also present, which are involved in reduction reaction within the bacteria. 4 lipase enzymes which are important in hydrolysis of fat in human body were also identified.

Presence of 6 endonuclease and 5 mutase enzymes were found. Mutase enzymes are involved in the transfer of functional groups from one ring to another (Mishra et al. 2016).

\subsection{Transporters}

Transporters play a significant role for the survival of pathogens as they are involved in the transfer of nutrients to the bacteria. 66 different transporter proteins are present in Mycobacterium tuberculosis, out of which 5 ABC (ATPbinding cassettes) transporters hydrolyze the ATP and transfer the nutrient to the bacteria. 31 membrane proteins are present which are important for the survival of pathogens. 4 lipoproteins are essential for the transfer of fats into the blood. 20 ATPase type transporter proteins are present which utilize energy and transfer it to bacteria (Geider and Hoffmann-Berling 1981). Such transporter proteins are important for the survival of the bacteria and may be beneficial for drug discovery. 
Table 1 List of annotated function of ten proteins with known function from Mycobacterium tuberculosis H37Rv using BLASTp, HMMER, INTERPROSCAN, SUPERFAMILY and Pfam for ROC analysis

\begin{tabular}{|c|c|c|c|c|c|c|}
\hline $\begin{array}{l}\text { S. } \\
\text { no. }\end{array}$ & $\begin{array}{l}\text { Protein } \\
\text { name }\end{array}$ & HMMER/HMMSCAN & Major blast hit & INTERPROSCAN & Pfam (family/domain) & SUPERFAMILY \\
\hline 1. & $\begin{array}{l}\text { HP } \\
\text { Rv0004 }\end{array}$ & $\begin{array}{l}\text { Protein of unknown } \\
\text { function (DUF721) } \\
14\end{array}$ & $\begin{array}{l}\text { RNA-binding } \\
\text { protein } \\
14\end{array}$ & $\begin{array}{l}\text { Protein of unknown } \\
\text { function (DUF721) } \\
14\end{array}$ & $\begin{array}{l}\text { Protein of unknown } \\
\text { function (DUF721) } \\
14\end{array}$ & $\begin{array}{l}\text { Metallo-dependent } \\
\text { hydrolases } \\
14\end{array}$ \\
\hline 2. & $\begin{array}{l}\text { HP } \\
\text { Rv0021C }\end{array}$ & $\begin{array}{l}\text { Nitronatemonooxygenase } \\
15\end{array}$ & $\begin{array}{l}\text { Oxidoreductase } \\
13\end{array}$ & $\begin{array}{l}\text { Nitronatemonooxygenase } \\
15\end{array}$ & $\begin{array}{l}\text { Nitronatemonooxygenase } \\
15\end{array}$ & $\begin{array}{l}\text { Inosine } \\
\text { monophosphate } \\
\text { dehydrogenase } \\
\text { (IMPDH) } \\
13\end{array}$ \\
\hline 3. & $\begin{array}{r}\text { HP Rv } \\
0025\end{array}$ & $\begin{array}{l}\text { Domain of unknown } \\
\text { function (DUF4226) } \\
14\end{array}$ & $\begin{array}{l}\text { Biofilm } \\
\text { regulator } \\
15\end{array}$ & $\begin{array}{l}\text { Domain of unknown } \\
\text { function (DUF4226) } \\
14\end{array}$ & $\begin{array}{l}\text { Domain of unknown } \\
\text { function (DUF4226) } \\
14\end{array}$ & $\begin{array}{l}\text { No hit found } \\
01\end{array}$ \\
\hline 4. & $\begin{array}{l}\text { HP } \\
\text { Rv0026 }\end{array}$ & $\begin{array}{l}\text { Domain of unknown } \\
\text { function (DUF4226) } \\
14\end{array}$ & $\begin{array}{l}\text { Biofilm } \\
\text { regulator } \\
15\end{array}$ & $\begin{array}{l}\text { Domain of unknown } \\
\text { function (DUF4226) } \\
14\end{array}$ & $\begin{array}{l}\text { Domain of unknown } \\
\text { function (DUF4226) } \\
14\end{array}$ & $\begin{array}{l}\text { No hit found } \\
01\end{array}$ \\
\hline 5. & $\begin{array}{l}\text { HP } \\
\text { Rv0027 }\end{array}$ & $\begin{array}{l}\text { Excreted virulence factor } \\
\text { EspC, type VII ESX } \\
\text { diderm } \\
15\end{array}$ & $\begin{array}{l}\text { ESX-1 } \\
\text { secretion- } \\
\text { associated } \\
\text { protein } \\
15\end{array}$ & $\begin{array}{l}\text { ESX-1 secretion- } \\
\text { associated protein } \\
15\end{array}$ & $\begin{array}{l}\text { Excreted virulence factor } \\
\text { espc, type VII ESX } \\
\text { diderm } \\
15\end{array}$ & $\begin{array}{l}\text { Sigma3 and } \\
\text { sigma4 domains } \\
\text { of RNA } \\
\text { polymerase } \\
\text { sigma factors } \\
05\end{array}$ \\
\hline 6. & $\begin{array}{l}\mathrm{HP} \\
\mathrm{RvOO} 28\end{array}$ & $\begin{array}{l}\text { Protein of unknown } \\
\text { function (DUF2694) } \\
01\end{array}$ & $\begin{array}{l}\text { DUF2694 } \\
\text { domain } \\
\text { containing } \\
\text { protein } \\
01\end{array}$ & $\begin{array}{l}\text { Protein of unknown } \\
\text { function (DUF2694) } \\
01\end{array}$ & $\begin{array}{l}\text { Protein of unknown } \\
\text { function (DUF2694) } \\
01\end{array}$ & $\begin{array}{l}\text { No hit found } \\
01\end{array}$ \\
\hline 7. & $\begin{array}{l}\text { HP } \\
\text { Rv0030 }\end{array}$ & $\begin{array}{l}\text { Protein of unknown } \\
\text { function (DUF2710) } \\
01\end{array}$ & $\begin{array}{l}\text { Transposase } \\
14\end{array}$ & $\begin{array}{l}\text { Protein of unknown } \\
\text { function (DUF2710) } \\
01\end{array}$ & $\begin{array}{l}\text { No hit found } \\
01\end{array}$ & $\begin{array}{l}\text { No hit found } \\
01\end{array}$ \\
\hline 8. & $\begin{array}{l}\text { HP } \\
\text { Rv0034 }\end{array}$ & $\begin{array}{l}\text { SnoaL-like domain } \\
15\end{array}$ & $\begin{array}{l}\mathrm{ACP} \\
13\end{array}$ & $\begin{array}{l}\text { SnoaL-like domain, } \\
\text { NTF2-like domain } \\
15\end{array}$ & $\begin{array}{l}\text { Protein of unknown } \\
\text { function (DUF2710) } \\
01\end{array}$ & $\begin{array}{l}\text { Ybab-like } \\
13\end{array}$ \\
\hline 9. & $\begin{array}{l}\text { HP } \\
\text { Rv0036 }\end{array}$ & $\begin{array}{l}\text { Mycothiolmaleylpyruvate } \\
\text { isomerase N-terminal } \\
\text { domain } \\
14\end{array}$ & $\begin{array}{l}\text { TIGR03084 } \\
\text { family protein } \\
14\end{array}$ & $\begin{array}{l}\text { Mycothiolmaleylpyruvate } \\
\text { isomerase N-terminal } \\
\text { domain, actinobacterial- } \\
\text { type } \\
14\end{array}$ & $\begin{array}{l}\text { Snoal-like domain } \\
13\end{array}$ & $\begin{array}{l}\text { NTF2-like } \\
14\end{array}$ \\
\hline 10. & $\begin{array}{l}\text { HP } \\
\text { Rv0038 }\end{array}$ & $\begin{array}{l}\text { Uncharacterized ACR, } \\
\text { COG1678 } \\
14\end{array}$ & $\begin{array}{l}\text { Transcriptional } \\
\text { regulator } \\
15\end{array}$ & $\begin{array}{l}\text { Protein of unknown } \\
\text { function UPF0301 } \\
01\end{array}$ & $\begin{array}{l}\text { Mycothiolmaleylpyruvate } \\
\text { isomerase N-terminal } \\
\text { domain } \\
14\end{array}$ & $\begin{array}{l}\text { Dinb/yfit-like } \\
\text { putative } \\
\text { metalloenzymes } \\
13\end{array}$ \\
\hline
\end{tabular}

\subsection{Binding proteins}

Out of 578 functionally annotated HPs, 36 proteins were predicted to be binding proteins with high level of confidence. Out of these 36 binding proteins, 10 DNA-binding proteins were identified, which are involved in the repair, storage, replication and transcription of DNA (Zhang and Rowley 2006). 7 RNA-binding proteins, which play significant roles in cellular function, transport, localization of proteins in bacteria, were identified. The presence of 4 protein binding, 12 domain containing and 3 exporter proteins were observed. Exporter proteins are similar to mRNA whose main functions are to transport the information from the nucleus to the cytoplasm (Pemberton and Paschal 2005). The information obtained from these proteins may prove to be valuable in the design of new drugs. 


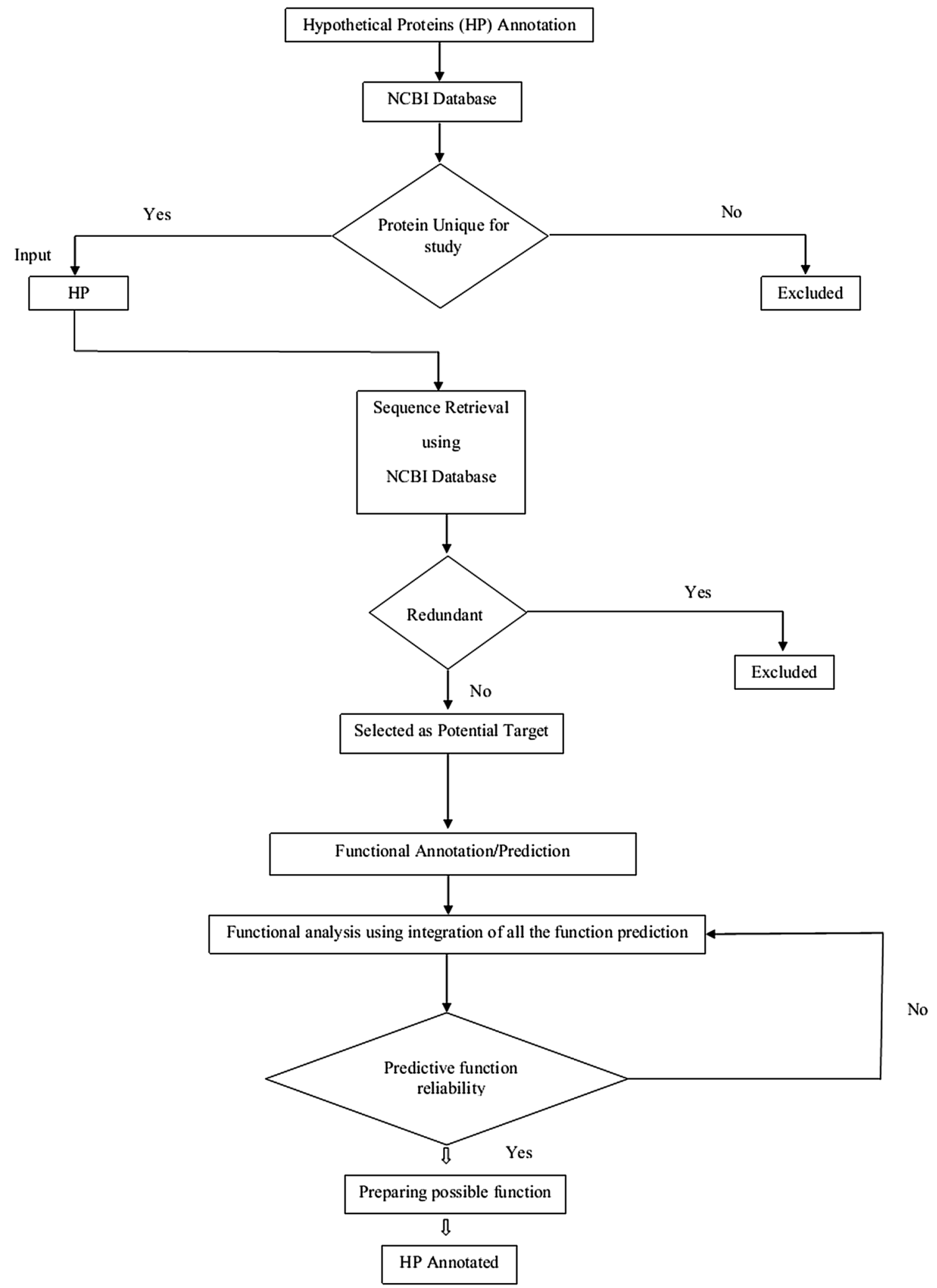

Fig. 2 Flowchart showing the overall methodology used in the annotation of HPs 
Fig. 3 Performance analysis of functional prediction tools using ROC analysis

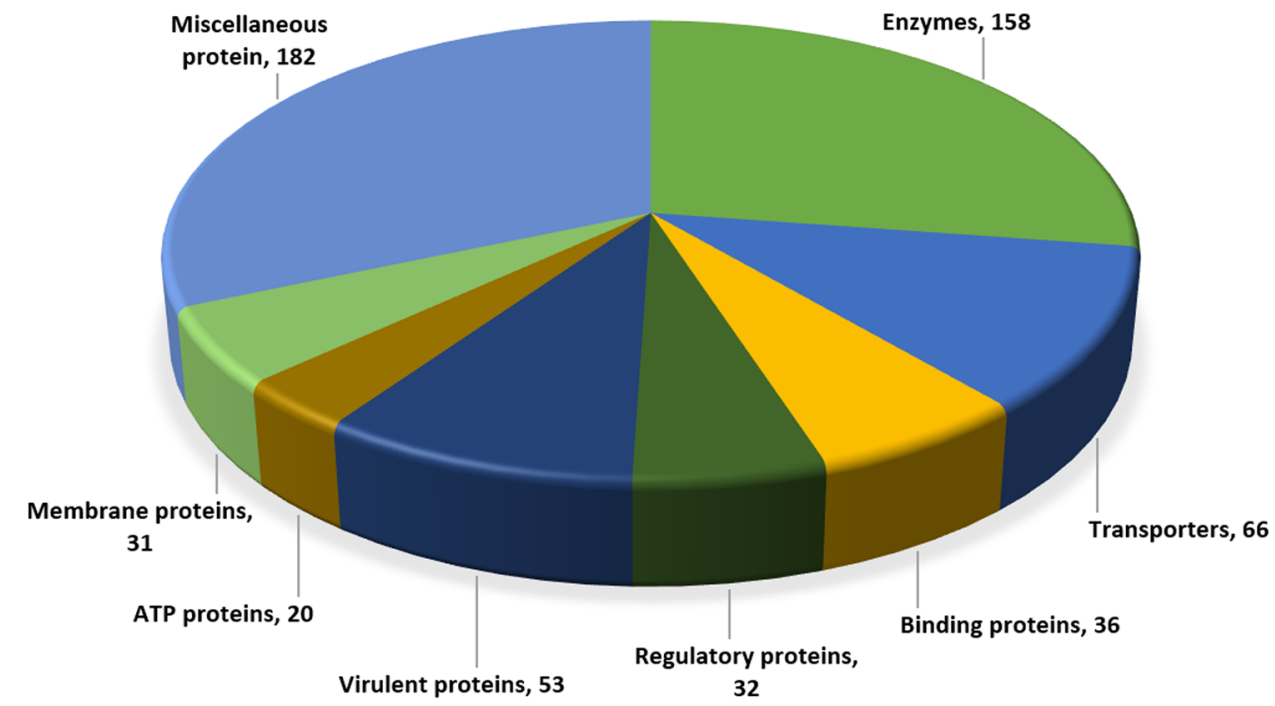

\begin{tabular}{llclll}
\hline S. no. & Software name & Accuracy of prediction $(\%)$ & Sensitivity $(\%)$ & Specificity $(\%)$ & ROC area \\
\hline 1. & HMMER & 98 & 97.9 & 100 & 0.989 \\
2. & BLAST & 100 & 100 & 100 & 1 \\
3. & INTERPROSCAN & 98 & 97.8 & 100 & 0.989 \\
4. & Pfam & 98 & 96.6 & 100 & 0.983 \\
5. & SUPERFAMILY & 98 & 96.8 & 100 & 0.984 \\
\hline
\end{tabular}

Table 2 List of accuracy, sensitivity, specificity and ROC area of various bioinformatics tools/softwares used in this study
The results from the ROC analysis as obtained from Fig. 3 indicate high reliability for the given bioinformatics tools (Mazandu and Mulder 2012; Ripon et al. 2016) (Table 2). The confidence of prediction for each HP was considered high if three or more of the tools give the same output. Using the pipeline, the accuracy for average HP was found to be $98.4 \%$. The pie chart in Fig. 4 shows the distribution of function across $578 \mathrm{HPs}$, of which 158 proteins act as enzymes, 66 HPs as transporters, 36 proteins for binding, 32 regulatory proteins, 53 virulent proteins, 20 ATP proteins, 31 membrane proteins and 182 being miscellaneous proteins, classified based on the flowchart represented in Fig. 2.

\section{Conclusions}

The occurrence of HPs in genomes constitutes a key issue for both the comparative as well as functional genomics investigations. Specifically for pathogenic living beings, these uncharacterized HPs obstruct the search for novel and more potent drug targets, and debilitate progress towards the development of research on these life forms and enhancement of our understanding of their virulence and pathogenicity. Analysis of the function, family and domain of 1055 HPs was conducted using various bioinformatics 


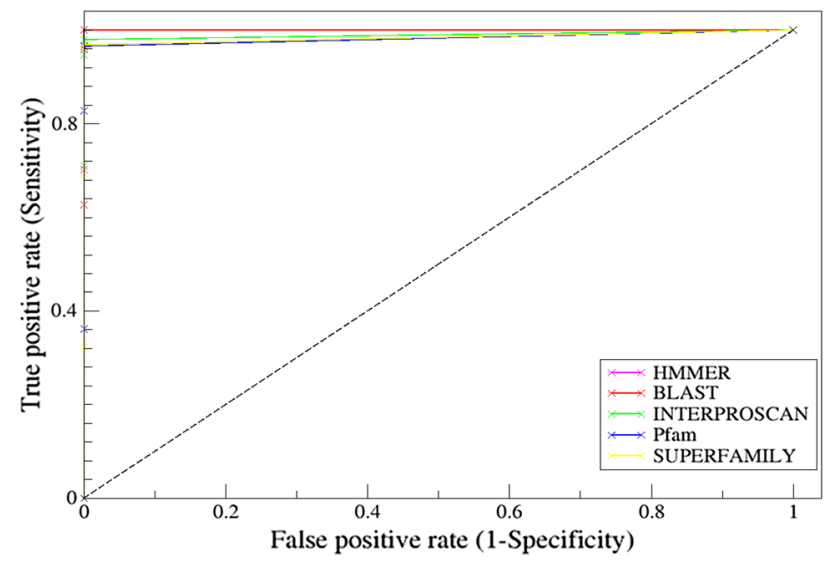

Fig. 4 Statistical analysis of 578 HPs processed using functional annotations from various bioinformatics tools

tools and the prediction of function of 578 HPs was made with high level of confidence. Various types of enzymes, transporter proteins, binding proteins, regulatory proteins and virulent proteins which play essential roles in the survival of Mycobacterium tuberculosis were identified and discussed. The information gathered from this study would be helpful in understanding the functions of hypothetical proteins present in Mycobacterium tuberculosis. The conclusions drawn for Mycobacterium proteins are expected to be generally valid for all pathogens. Hence, an in silico approach for functional annotation of HPs can facilitate further studies on these HPs as novel putative drug targets for other clinically important pathogens (Fig. 4).

Acknowledgements The authors acknowledge the Department of Applied Sciences, Indian Institute of Information Technology, Allahabad, for providing computing facility.

\section{References}

Altschul SF, Gish W, Miller W, Myers EW, Lipman DJ (1990) Basic local alignment search tool. J Mol Biol 215(3):403-410

Cantoni GL (1952) The nature of the active methyl donor formed enzymatically from L-methionine and adenosinetriphosphate $1,2$. J Am Chem Soc 74(11):2942-2943

Chowdhury L, Khan MI, Deb K, Kamal S (2016) MetaG: a graphbased metagenomic gene analysis for big DNA data. Netw Model Anal Health Inform Bioinform 5(1):1-16

Emanuelsson O, Brunak S, von Heijne G, Nielsen H (2007) Locating proteins in the cell using TargetP, SignalP and related tools. Nat Protoc 2(4):953-971

Fu LM, Fu-Liu CS (2002) Is Mycobacterium tuberculosis a closer relative to Gram-positive or Gram-negative bacterial pathogens? Tuberculosis 82(2):85-90

Garg A, Gupta D (2008) VirulentPred: a SVM based prediction method for virulent proteins in bacterial pathogens. BMC Bioinform 9(1):1

Gasteiger E, Gattiker A, Hoogland C, Ivanyi I, Appel RD, Bairoch A (2003) ExPASy: the proteomics server for in-depth protein knowledge and analysis. Nucleic Acids Res 31(13):3784-3788
Geider K, Hoffmann-Berling H (1981) Proteins controlling the helical structure of DNA. Annu Rev Biochem 50(1):233-260

Gough J, Karplus K, Hughey R, Chothia C (2001) Assignment of homology to genome sequences using a library of hidden Markov models that represent all proteins of known structure. J Mol Biol 313(4):903-919

Gupta P, Raj U, Varadwaj PK (2015) Computational intelligence in data mining. In: Jain LC, Behera HS, Mandal JK, Mohapatra DP (eds) Proceedings of the International Conference on CIDM, 20-21 December 2014, vol. 1, pp 447-458. Springer, India

Gupta S, Singh Y, Kumar H, Raj U, Rao AR, Varadwaj PK. (2016) Identification of novel abiotic stress proteins in Triticum aestivum through functional annotation of hypothetical proteins. Interdiscip Sci Comput Life Sci. doi:10.1007/s12539016-0178-3

Ioerger TR, Feng Y, Ganesula K, Chen X, Dobos KM, Fortune S, Jacobs WR, Mizrahi V, Parish T, Rubin E, Sassetti C (2010) Variation among genome sequences of H37Rv strains of Mycobacterium tuberculosis from multiple laboratories. J Bacteriol 192(14):3645-3653

Kamal MS, Nimmy SF (2016) StrucBreak: a computational framework for structural break detection in DNA sequences. Interdiscip Sci Comput Life Sci. doi:10.1007/s12539-016-0158-7

Kamal MS, Nimmy SF, Parvin S (2016a) Performance evaluation comparison for detecting DNA structural break through big data analysis. Comput Syst Sci Eng 31:1-15

Kamal S, Ripon SH, Dey N, Ashour AS, Santhi V (2016b) A MapReduce approach to diminish imbalance parameters for big deoxyribonucleic acid dataset. Comput Methods Programs Biomed 131:191-206

Krogh A, Larsson B, Von Heijne G, Sonnhammer EL (2001) Predicting transmembrane protein topology with a hidden Markov model: application to complete genomes. J Mol Biol 305(3):567-580

Kumar A, Shanmughavel P (2011) Computational annotation for hypothetical proteins of Mycobacterium tuberculosis. J Comput Sci Syst Biol 1:050-062

Latchman DS (1997) Transcription factors: an overview. Int J Biochem Cell Biol 29(12):1305-1312

Mazandu GK, Mulder NJ (2012) Functional prediction and analysis of Mycobacterium tuberculosis hypothetical proteins. Int J Mol Sci 13(6):7283-7302

Mishra S, Raj U, Varadwaj PK (2016) Annotation of hypothetical proteins: a functional genomics approach. In: Computational Biology and Bioinformatics, vol. 2016, CRC Press, pp 135-158. doi:10.1201/b20026-10

Munksgaard B (2004) Mycobacterium tuberculosis. Am J Transplant 4(Suppl 10):37-41

Nambi S, Long JE, Mishra BB, Baker R, Murphy KC, Olive AJ, Nguyen HP, Shaffer SA, Sassetti CM (2015) The oxidative stress network of Mycobacterium tuberculosis reveals coordination between radical detoxification systems. Cell Host Microbe 17(6):829-837

Nancy YY, Wagner JR, Laird MR, Melli G, Rey S, Lo R, Dao P, Sahinalp SC, Ester M, Foster LJ, Brinkman FS (2010) PSORTb 3.0: improved protein subcellular localization prediction with refined localization subcategories and predictive capabilities for all prokaryotes. Bioinformatics 26(13):1608-1615

Noda-García L, Juárez-Vázquez AL, Ávila-Arcos MC, VerduzcoCastro EA, Montero-Morán G, Gaytán P, Carrillo-Tripp M, Barona-Gómez F (2015) Insights into the evolution of enzyme substrate promiscuity after the discovery of $(\beta \alpha) 8$ isomerase evolutionary intermediates from a diverse metagenome. BMC Evol Biol 15(1):1

Pemberton LF, Paschal BM (2005) Mechanisms of receptor-mediated nuclear import and nuclear export. Traffic 6(3):187-198 
Rai S, Raj U, Tichkule S, Kumar H, Mishra S, Sharma N, Buddham R, Raghav D, Varadwaj PK (2016) Recent trends in in-silico drug discovery. Int J Comput Biol (IJCB) 5(1):54-76

Raj U, Kumar H, KumarVaradwaj P (2015a) 3D structure generation, molecular dynamics and docking studies of IRHOM2 protein involved in cancer \& rheumatoid arthritis. Curr Comput Aided Drug Des 11(4):325-335

Raj U, Kumar H, Gupta S, Varadwaj PK (2015b) Novel DOT1L receptor natural inhibitors involved in mixed lineage leukemia: a virtual screening, molecular docking and dynamics simulation study. Asian Pac J Cancer Prev 16(9):3817-3825

Raj U, Kumar H, Gupta S, Varadwaj PK (2015c) Exploring dual inhibitors for STAT1 and STAT5 receptors utilizing virtual screening and dynamics simulation validation. J Biomol Struct Dyn 20:1-5

Raj U, Kumar H, Varadwaj PK (2016) Molecular docking and dynamics simulation study of flavonoids as BET bromodomain inhibitors. J Biomol Struct Dyn 5:1-2
Ripon SH, Kamal S, Hossain S, Dey N (2016) theoretical analysis of different classifiers under reduction rough data set: a brief proposal. Int J Rough Sets Data Anal (IJRSDA) 3(3):1-20

Saha S, Raghava GPS (2006) VICMpred: an SVM-based method for the prediction of functional proteins of Gram-negative bacteria using amino acid patterns and composition. Genom Proteom Bioinform 4(1):42-47

Söding J, Biegert A, Lupas AN (2005) The HHpred interactive server for protein homology detection and structure prediction. Nucleic Acids Res 33(suppl 2):W244-W248

Yu CS, Chen YC, Lu CH, Hwang JK (2006) Prediction of protein subcellular localization. Proteins: Struct, Funct, Bioinf 64(3):643-651

Zhang Y, Rowley JD (2006) Chromatin structural elements and chromosomal translocations in leukemia. DNA Repair 5(9):1282-1297 